\title{
Continuous retrobulbar anesthesia for scleral buckling surgery using an ultra-fine spinal anesthesia catheter
}

\author{
[L'anesthésie rétrobulbaire continue pendant le cerclage scléral à l'aide d'un \\ cathéter ultra-fin pour la rachianesthésie]
}

Jost B. Jonas MD, ${ }^{*}$ Melanie Jäger, ${ }^{*}$ Thomas M. Hemmerling MD $\dagger$

Purpose: To evaluate a novel retrobulbar catheter technique for intraoperative and postoperative analgesia in patients undergoing scleral buckling procedures.

Methods: This prospective noncomparative clinical interventional case-series study included 43 consecutive patients undergoing scleral buckling procedures as treatment of rhegmatogenous retinal detachments. Using a commercially available retrobulbar needle with a diameter of $0.80 \mathrm{~mm}$ and a length of $38 \mathrm{~mm}, 7 \mathrm{~mL}$ of local anesthetic were injected into the retrobulbar space. Through the same needle, a 28-gauge commercially available flexible spinal anesthesia catheter was introduced into the retrobulbar space, the needle was withdrawn, and the catheter was fixed. The catheter was removed on the morning of the first postoperative day. When the patients started to feel pain during or after surgery, $2 \mathrm{~mL}$ of local anesthetic were re-injected through the catheter.

Results: During surgery, 12 (27.9\%) patients received a pain-free re-injection through the retrobulbar catheter resulting in a marked reduction of pain. Two (4.7\%) patients needed a second re-injection. In the postoperative period, 23 (53.5\%) patients experienced pain of grade 3 or higher $5.4 \pm 6.7 \mathrm{hr}$ after start of surgery and received a retrobulbar re-injection. Eleven (25.6\%) patients asked for a second postoperative re-injection, and four (9.3\%) patients received a third postoperative re-injection. Cardiopulmonary and central nervous adverse effects were not noticed.

Conclusions: Use of an ultra-fine retrobulbar catheter for repeat intraoperative and postoperative injections of local anesthetics is a simple and effective method to achieve analgesia during and after scleral buckling procedures.
Objectif : Évaluer une nouvelle technique avec cathéter rétrobulbaire pour l'analgésie peropératoire et postopératoire chez des patients qui subissent un cerclage scléral.

Méthode : L'étude clinique prospective interventionnelle non comparative de cas-séries comprenait 43 patients consécutifs devant subir un cerclage scléral comme traitement d'un décollement rhegmatogène de la rétine. On a injecté $7 \mathrm{~mL}$ d'anesthésique local dans l'espace rétrobulbaire à l'aide d'une aiguille rétrobulbaire de commerce, d'un diamètre de $0,80 \mathrm{~mm}$ et d'une longueur de $38 \mathrm{~mm}$. Un cathéter flexible de calibre 28 pour la rachianesthésie, a été introduit au travers de cette même aiguille dans l'espace rétrobulbaire. Puis, l'aiguille a été retirée et le cathéter fixé. Le cathéter a été enlevé le matin du premier jour postopératoire. Dès le début des douleurs ressenties pendant ou après l'opération, $2 \mathrm{~mL}$ d'anesthésique local ont été injectés par le cathéter.

Résultats : Pendant l'opération, 12 (27,9\%) patients ont reçu une réinjection d'analgésique par le cathéter rétrobulbaire, ce qui a grandement réduit les douleurs. Deux (4,7\%) patients ont eu besoin d'une seconde réinjection. Après l'opération, 23 (53,5\%) patients ont ressenti des douleurs de classe 3 ou plus 5,4 \pm 6,7 h après le début de l'intervention et ont reçu une réinjection rétrobulbaire. Onze (25,6 \%) patients ont demandé une seconde réinjection postopératoire et quatre (9,3\%) en ont reçu une troisième. Aucun effet indésirable, affectant le système nerveux central ou cadio-pulmonaire, n'a été noté.

Conclusion : L'usage d'un cathéter rétrobulbaire ultra-fin pour des injections peropératoires et postopératoires répétées d'anesthésique local est une méthode simple et efficace d'administrer l'analgésie pendant et après un cerclage scléral.

From the Department of Ophthalmology and Eye Hospital, ${ }^{*}$ Faculty of Clinical Medicine Mannheim, University of Heidelberg, Mannheim, Germany, and the Department of Anesthesiology, $†$ Centre Hospitalier de l'Université de Montréal (CHUM), University of Montréal, Montréal, Québec, Canada. Address correspondence to: Dr. J. Jonas, Universitäts-Augenklinik, Theodor-Kutzer-Ufer 1-3, 68167 Mannheim, Germany. Phone: **49-

621-383-2652; Fax: **49-621-383-3803; E-mail: Jost.Jonas@augen.ma.uni-heidelberg.de Accepted for publication December 20, 2001.

Revision accepted February 12, 2002. 
S

CLERAL buckling procedures for the treatment of rhegmatogenous retinal detachment generally are more painful than operations in the anterior segment of the eye because scleral buckling procedures involve orbital tissue with stretching of the external ocular muscles. Topical anesthesia as used for cataract surgery is, therefore, not useful for scleral buckling surgery, and peribulbar or retrobulbar anesthesia is not always effective to sufficiently reduce pain. ${ }^{1,2}$ The purpose of the present study was to evaluate prospectively the suitability of a new technique, the retrobulbar catheter technique, for anesthesia during and after scleral buckling procedures. ${ }^{3}$

\section{Materials and methods}

The prospective clinic-based study included 43 consecutive patients who underwent scleral buckling surgery as treatment of rhegmatogenous retinal detachment, and who were operated on by the same surgeon with retrobulbar anesthesia. The procedure had been approved by the University Ethics Committee according to the declaration of Helsinki. Mean age of patients was $65.2 \pm 9.1 \mathrm{yr}$ (mean \pm SD; range, $4 \mathrm{l}$ to $8 \mathrm{l} \mathrm{yr}$ ). Exclusion criteria were an axial length of the globe longer than $26 \mathrm{~mm}$, myopia of more than -6 diopters, and inability of the patient to lie down for the operation for more than two hours.

The scleral buckling procedure included use of an encircling band ( $n=23$ patients), a scleral buckle ( $n=$ $25)$, transscleral retinal exocryocoagulation $(n=43)$, and transscleral exodrainage of the subretinal fluid $(n$ $=25)$. Mean duration of surgery was $55.2 \pm 16.9 \mathrm{~min}$ (range, 20-105 $\mathrm{min}$ ). Preoperatively, the patients had routinely received 1 or $2 \mathrm{mg}$ lorazepam orally as sedative medication.

Using a commercially available custom-made retrobulbar needle (length: $38 \mathrm{~mm}$ ) with an outer diameter of $0.80 \mathrm{~mm}$ (Geuder GmbH, Hertzstrasse, D-99126 Heidelberg, Germany), $7 \mathrm{~mL}$ of mepivacaine $2 \%$ ( $n=$ $37)$, bupivacaine $0.50 \%(n=2)$ or ropivacaine $0.75 \%(n$ $=4$ ) were injected from the temporal inferior position transcutaneously into the retrobulbar space prior to the operation. Through the needle in place, a 28-gauge catheter (Kendall GmbH, D-93333 Neustadt, Germany), the same that is used for spinal anesthesia, was introduced into the retrobulbar space, and the needle was withdrawn. After removal of the stylet from the catheter, a $0.20 \mu$ bacterial filter was attached, the catheter taped to the skin, and $1 \mathrm{~mL}$ of local anesthetic injected to purge the catheter.

During surgery, the patients were monitored and asked every ten to $15 \mathrm{~min}$, whether they were comfortable or experienced pain. In a similar manner, the patients were asked regularly after surgery whether they started to feel pain. For this purpose, we had explained a pain scale to the patients with 0 for no pain and 10 for maximal pain. Each time the patients started to feel painful sensations of grade 3 or higher on the pain scale, $2 \mathrm{~mL}$ of local anesthetic were reinjected. The catheters were removed on the morning of the first postoperative day.

\section{Results}

Introducing the catheter into the parabulbar or retrobulbar space was possible in all patients. The procedure took less than five minutes including fixation of the catheter. Correspondingly, removal of the catheter after surgery was unremarkable. The catheter entry site was inspected regularly up to three days after surgery, and local or systemic infections or irritations were not detected. Postoperative diplopia or other ocular motility problems were not detected. During surgery, swelling of the lids or the conjunctiva was not observed.

Intraoperatively, $12(27.9 \%)$ patients asked for a reinjection after which a pain score of less than 2 was achieved within one to two minutes of injection. Mean interval between start of the operation and the first reinjection was $36.3 \pm 30.6 \mathrm{~min}$ (median, $30 \mathrm{~min}$; range, 5 to $100 \mathrm{~min}$ ). Two $(4.7 \%)$ patients needed a second reinjection, 20 to $55 \mathrm{~min}$ after start of surgery. A re-injection was performed in three of $17(17.6 \%)$ patients with a duration of surgery shorter than $50 \mathrm{~min}$, in seven of $19(36.8 \%)$ patients with a duration of surgery longer than $50 \mathrm{~min}$, and in four of nine (44.4\%) patients with a duration of surgery longer than $60 \mathrm{~min}$. Mean volume of mepivacaine administered during surgery was $11.2 \pm$ $2.1 \mathrm{~mL}$ (median, $11 \mathrm{~mL}$; range, $8-16 \mathrm{~mL}$ ). At the end of surgery, a subconjunctival injection of gentamicine was given and did not cause pain of grade 3 or higher.

Postoperatively, $23(53.5 \%)$ patients experienced pain of grade 3 or higher $5.4 \pm 6.7 \mathrm{hr}$ after the start of surgery and received a re-injection of the local anesthetic which markedly reduced pain to grade 0 to 2 on the pain scale. Eleven $(25.6 \%)$ patients asked for a second postoperative re-injection $6.0 \pm 4.9 \mathrm{hr}$ after the start of surgery, and four $(9.3 \%)$ patients received a third postoperative re-injection $9.3 \pm 3.3 \mathrm{hr}$ after the start of surgery. Cardiopulmonary and central nervous adverse effects were not noticed by the attending anesthesiologist.

The mobility of the patients in the postoperative period was not restricted by the catheter. The patients could move around freely, read the newspapers or watch television. Asked whether they would receive this kind of postoperative local anesthesia again, 90.7\% of the patients answered positively. The remaining 
patients were either undecided or preferred a re-operation under general anesthesia.

\section{Discussion}

The retrobulbar catheter technique is a relatively new procedure which allows multiple re-injections of the local anesthetic through a retrobulbar or parabulbar catheter, avoiding repetitive retrobulbar block. The use of an ultra-fine, spinal anesthesia catheter can be regarded as a further refinement of peribulbar or retrobulbar techniques in which catheters have already been inserted into the peribulbar or retrobulbar space to maintain anesthesia. ${ }^{4-8}$ The results of the present study suggest that a flexible temporary retrobulbar catheter may be useful to provide local anesthesia for patients undergoing scleral buckling procedures. In all patients included in the study, repetitive injections through the retrobulbar catheter were painless, partially or completely relieved ocular or orbital pain within one to two minutes, and were performed without complications, whether reinjections were performed during surgery or in the postoperative period. The experience gathered so far with this novel technique suggests that it may prolong intraoperative anesthesia and provide postoperative analgesia in patients undergoing scleral buckling surgery.

\section{References}

1 Feibel RM. Current concepts in retrobulbar anesthesia. Surv Ophthalmol 1985; 30: 102-10.

2 Sharma T, Gopal L, Parikh S, Shanmugam MP, Badrinath SS, Mukesh BN. Parabulbar anesthesia for primary vitreoretinal surgery. Ophthalmology 1997; 104: 425-8.

3 Jonas JB, Hemmerling TM, Budde WM, Dinkel M. Postoperative analgesia by reinjections of local anesthetic through an indwelling retrobulbar catheter. Am J Ophthalmol 2000; 129: 54-8.

4 Tamai $M$. A retained retrobulbar catheter for repetitive injection of anesthetics during ophthalmic surgery. Ophthalmic Surg 1983; 14: 579-81.

5 Poupard P, Aubry I, Bonnet S, Eledjam JJ, Arnaud B. Une nouvelle technique d'ALR en ophtalmologie: le cathétérisme retrobulbaire extra-conique. Ophtalmologie 1991; 5: 293-4.

6 Dantas PE, Nishiwaki-Dantas MC, Henriques MJ, de Almeida $G V$. Retrobulbar anesthesia with a flexible catheter. Ophthalmic Surg Lasers 1996; 27: 275-8.

7 Bernard JM, Hommeril JL. Prolonged peribulbar anaesthesia with indwelling catheter: a preliminary report of 217 cases. Br J Anaesth 1997; 78 : 81-2.

8 Behndig A. Sub-Tenon's anesthesia with a retained catheter in ocular surgery of longer duration. J Cataract Refract Surg 1998; 24: 1307-9. 